\title{
Optimization of Incubation Period, pH and Moisture Content for Vermicomposting of Biomethanation Sludge Admixed with Fruits and Vegetable Waste Collected from Gultekadi Market Yard, Pune Using Eudrilus eugeniae
}

\author{
A. I. Mulla* and G.R. Pathade** \\ *Department of Environmental Science, Fergusson College, Pune, Maharashtra, India \\ **Department of Microbiology, H.V. Desai College, Pune, Maharashtra, India \\ $†$ Corresponding author: A. I. Mulla; amir.karad@gmail.com
}

Nat. Env. \& Poll. Tech.

Website: www.neptjournal.com

Received: 20-08-2019

Accepted: 26-11-2019

\section{Key Words:}

Vermicomposting;

Biomethanation;

Sludge;

Eudrilus eugeniae

\begin{abstract}
The present study had an objective to optimize important parameters viz., incubation period, $\mathrm{pH}$ and moisture per cent for vermicomposting of biomethanation sludge admixed with fruits and vegetable waste collected from Gultekadi Market Yard, Pune using Eudrilus eugeniae. The experiment was conducted on the terrace of H.V. Desai College of Arts, Commerce and Science, Pune. The sludge from biomethanation digester running on fruits and vegetable waste was collected and dewatered. The fruits and vegetable waste was collected from Gultekadi Market Yard, Pune and used for the experiment by processing it. The dewatered sludge was admixed with partially decomposed fruits and vegetable waste. The $1 \mathrm{~kg}$ working capacity plastic trays were used for the optimization of parameters. It was found that incubation period of six weeks, $\mathrm{pH} 7.0$ and moisture content of $70-80 \%$ were the optimum condition for Eudrilus eugeniae vermicomposting. The average growth rate $\mathrm{mg} / \mathrm{worm} / \mathrm{day}$ for the optimized incubation period, $\mathrm{pH}$ and moisture $\%$ was $4.4 \pm 0.14,5.57 \pm 0.1$ and $7.5 \pm 0.47$, respectively and at all the three optimized conditions was $7.8 \pm 0.6$.
\end{abstract}

\section{INTRODUCTION}

The vermicomposting is the use of earthworms for the treatment of organic waste to get mineralized humus like manure (Ansari \& Ismail 2012). The vermicomposting is an environmentally sound technique of waste management. The technique is effective for partially decomposed organic waste such as market waste, agricultural waste, kitchen waste, industrial anaerobic treatment's sludge etc. The earthworms can consume biomass/food equivalent to their body weight in a day (Gurav \& Pathade 2011). The earthworms are used to degrade waste material into economically profitable manure. India has an agricultural economy (Mathew 2006) and so organic waste generated like fruits and vegetable waste (FVW), can be managed through earthworms. India has a tropical climate and more than 500 earthworm species are reported from different parts of the nation. The vermicomposting with selected earthworm species is an effective solution for organic waste management. The vermicompost contains a higher amount of nutrients required for plant growth, especially nitrogen, phosphorus and potassium along with other micronutrients (Bansal \& Kapoor 2000). Devi et al. (2012) and Hemalatha (2013) and many others have worked on fruit waste management using vermicomposting technique and produced good quality vermicompost.

The earthworms are of three types as per their preference to food and habitat (Butt \& Lowe 2011). The first one is epigeic earthworms, prefer to be on the top layer of soil and get their food from decomposed organic matter of leaf litter (Gajalakshmi \& Abbasi 2004). The examples of epigeic worms are Eisenia andrei, Lumbricus rubellus, Eisenia fetida (Ef), Eudrilus eugeniae (Ee). The epigeic earthworms possess high metabolic activities which make them a good choice for vermicomposting (Kale \& Bano 1992). The endogenic earthworms are the second category. An endogenic earthworm stays below the top layer of soil where mineralized soil is present. They make horizontal burrows to the top layer of soil and feed on the organic matter of the soil. The third category of earthworms is anecic earthworms which prefer to stay in deep burrows but come to the top surface for feeding (Kadam \& Pathade 2004).

\section{MATERIALS AND METHODS}

\section{Earthworm Used}

The earthworm used was Eudrilus eugeniae whose taxonomical classification is given in Table 1. A photograph of the earthworm species is presented in Fig. 1. 


\section{Biomethanation Plant Sludge and FVW as Feed}

The biomethanation project was undertaken with FVW. The effluent from biogas digester was subjected for the separation of solids (Biogas Digester Sludge-BDS) and the liquid portion. The liquid portion was used as fertilizer to the plants while the solid portion was mixed with Partially Decomposed Fruits and Vegetable Waste (PDFVW). This admixture was then subjected as feed to the vermicomposting. The vermicomposting in the laboratory was performed in the plastic trays of $5 \mathrm{~kg}$ capacity with working volume $1 \mathrm{~kg}$ (Mane \& Raskar 2012). Using same trays, the vermicomposting process parameters, e.g. incubation period, $\mathrm{pH}$ and moisture were optimized as per Kadam \& Pathade (2004), while the ambient temperature was used as incubation temperature and was around $25-30^{\circ} \mathrm{C}$.

\section{Vermicompost Pots}

The present experiments were carried out in $1 \mathrm{~kg}(25 \mathrm{~cm} \times 17 \mathrm{c}-$ $\mathrm{m} \times 7 \mathrm{~cm}$ ) working capacity plastic trays. All the trays of 1

Table 1: Classification of Eudrilus eugeniae.

\begin{tabular}{|ll|}
\hline Rank & Classification \\
\hline Kingdom & Animalia \\
Phylum & Annelida \\
Class & Clitellata \\
Subclass & Oligochaeta \\
Order & Haplotaxida \\
Family & Eudrilidae \\
Genus & Eudrilus \\
Species & eugeniae \\
\hline
\end{tabular}

Source: https://en.wikipedia.org/wiki/Eudrilus_eugeniae $\mathrm{kg}$ capacity were provided with the facility for aeration and removal of vermiwash by making $1 \mathrm{~mm}$ sized holes at the base and all sides of walls of the tray for ventilation. All the trays were covered with cotton fabric and kept in the rack. The rack was covered with wet empty jute bags during the experiment to prevent infestation of insects and rodents and to maintain dark conditions to avoid direct exposure of sunlight during the experiment.

\section{Optimization Studies for Vermicomposting of FVW}

Acclimatization of earthworms to feed: The optimization of $\mathrm{pH}$ and moisture was an important part of the study. The initial $\mathrm{pH}$ of the feed was kept around 7.0 and moisture around $60-80 \%$. The one set in triplicate was performed with a selected range of $\mathrm{pH}-7$ and moisture (60-80\%). The earthworms were acclimatized to experimental conditions for six to eight weeks. The acclimatized earthworms were then used for the optimization studies.

\section{Optimization of the incubation period for vermicomposting} using the above substrate (feed): The experiment for incubation period was conducted in triplicate using the above substrate (feed) for earthworm species $E e$. The moisture of feed was maintained around 70 to $80 \%$ by manually spraying water regularly throughout the experiment. The $\mathrm{pH}$ of feed was maintained around 7.0. The ambient temperature during the experiment was around $25-30^{\circ} \mathrm{C}$. The ten juveniles/tray of each $E e$ species were released in respective trays containing $1 \mathrm{~kg}$ of feed/tray and trays were incubated as described above for 8 weeks of the incubation period. The weight gain/ tray/week by earthworms and mortality if any was recorded every week for all experimental sets. For the recording of weights, earthworms were removed from trays and washed with tap water. The blotting paper was used to blot/absorb excess water. The weight of earthworms was recorded and

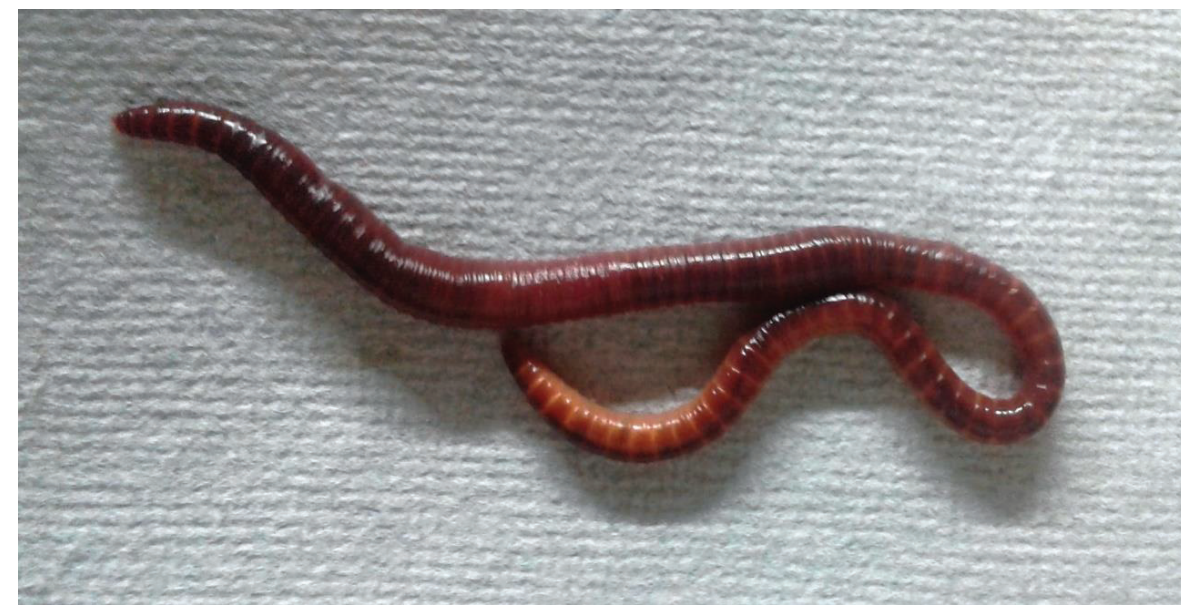

Fig. 1: The Adult earthworm, Eudrilus eugeniae. 
earthworms were released back in respective trays. The incubation period (weeks) at which maximum average weight gain in case of earthworms and maximum vermicompost amount was obtained, was taken as an optimum incubation period for vermicomposting.

The average growth rate ( $\mathrm{mg} /$ tray/day) of earthworm was calculated by the method of Manaf et al. (2009) and Suthar (2009). The formula used for the same is given in equation 1.

$\begin{gathered}\text { Earthworm growth rate } \\ (\mathrm{mg} / \text { tray/day })\end{gathered}=\frac{\begin{array}{c}\text { Maximum biomass }(\mathrm{mg})-\mathrm{In}- \\ \text { itial biomass }(\mathrm{mg})\end{array}}{\begin{array}{c}\text { Total number of days in } \\ \text { which biomass is obtained }\end{array}}$

The average growth rate (mg/worm/day) of earthworm was calculated by the method of Manyuchi \& Phir (2013). The formula used for the same is as given in equation 2 .

$\begin{gathered}\text { Earthworm growth rate } \\ (\mathrm{mg} / \text { worm/day })\end{gathered}=\frac{\begin{array}{c}\text { Maximum biomass }(\mathrm{mg}) \text {-Initial } \\ \text { biomass }(\mathrm{mg})\end{array}}{\begin{array}{c}\text { Total number of days in which } \\ \text { biomass is obtained } \times \\ \text { Number of earthworms } \\ \text { inoculated }\end{array}}$

Optimization of $\boldsymbol{p H}$ of feed for vermicomposting: The $\mathrm{pH}$ range selected for the experiment was $\mathrm{pH}$ 5.0, 6.0, 7.0, 8.0 and 9.0 for earthworms Eudrilus eugeniae. The experiments were run in triplicates. The ten juvenile earthworms of $E u$ drilus eugeniae species were released per tray. The entire experiment was conducted with the moisture content of up to $70-80 \%$ and an ambient temperature of $25-30^{\circ} \mathrm{C}$. The $\mathrm{pH}$ values of feed were adjusted with $1 \mathrm{~N} \mathrm{HCl} / 1 \mathrm{~N} \mathrm{NaOH}$. The initial weight of earthworms was recorded before releasing in trays. The weekly readings for average weight gain and mortality if any were recorded. The $\mathrm{pH}$ value of feed at which maximum weight gain in the inoculated earthworms and average maximum vermicompost obtained, was considered as optimum $\mathrm{pH}$ of the feed. The experiment was run for six weeks (six weeks was the optimum incubation period obtained in the previous experiment (Fig. 2).

Optimization of moisture content of feed for vermicomposting: The moisture range used was 50-60, 60-70, 70-80 and $80-90 \%$ for the earthworms. The experiments were run in triplicates. The entire experiments were conducted by maintaining $\mathrm{pH} 7.0$ of feed (optimized condition) and at ambient temperature $\left(25-30^{\circ} \mathrm{C}\right)$ for feed and six weeks incubation period (optimized). The 10 juvenile earthworms were released/tray. The initial weights of earthworms were recorded before releasing in the trays. The feed provided with various moisture ranges were monitored for growth of earthworms. The weekly readings were recorded for average weight gain, the final amount of vermicompost and mortality if any. The moisture value of feed at which maximum weight gain in the inoculated earthworms and average maximum vermicompost produced was taken as optimum moisture range value of the feed (Fig. 3).

\section{Vermicomposting Using Optimized Conditions}

The experiment was performed in triplicates for Eudrilus eugeniae earthworm species. The optimized conditions

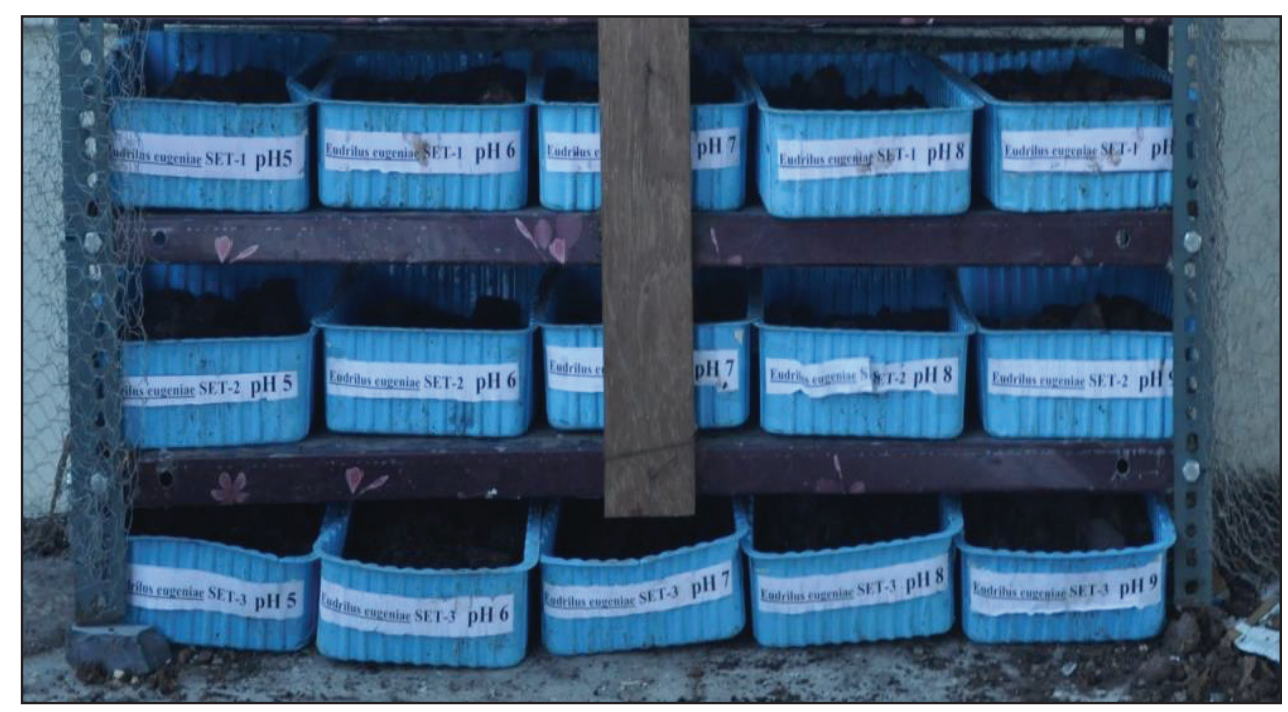

Fig. 2: Vermicomposting trays in the racks for the experiment of optimization of $\mathrm{pH}$ of feed. 
obtained from the above experiments for Eudrilus eugeniae species were used to perform in this experiment. The $1 \mathrm{~kg}$ feed prepared with optimized conditions was used for this experiment. The 10 juvenile earthworms were released/tray. The initial weights of earthworms were recorded before releasing in the trays. The average maximum weight gain and average maximum vermicompost produced for the experimental period (six weeks) were recorded weekly/ tray.

\section{RESULTS AND DISCUSSION}

\section{Optimization Studies for Vermicomposting of BDS and PDFVW}

Optimization of incubation period: It is evident from Table 2 and Fig. 4 that there was a gradual increase in weight gain from week one $(166.83 \pm 20.42)$ to week six $(1936.64 \pm 64.05)$ and average maximum weight gain by $E e$ earthworm species was recorded at $6^{\text {th }}$ week. The further incubation on $7^{\text {th }}$ week onwards resulted in weight loss. The average maximum weight gains for three sets of were obtained as $1936.64 \pm 64.05$ $\mathrm{mg}$. The weight loss in $7^{\text {th }}$ and $8^{\text {th }}$ week indicated nutrient deficiency, thus the optimum incubation period for $\mathrm{Ee}$ species was taken as six weeks. The average growth rate $(\mathrm{mg} / \mathrm{worm} /$ day) and vermicompost obtained ( $\mathrm{g} / \mathrm{kg}$ of feed) for $E e$ were reported as $4.4 \pm 0.14$ and $348.9 \pm 21.5$ respectively. Hence, six weeks was considered as an optimum incubation period.
The previous study by Pandit \& Maheshwari (2012) reported growth of Eisenia fetida with optimum of 6 weeks with $\mathrm{pH} 7.0$, particle size $1-2 \mathrm{~mm}$, temperature $25^{\circ} \mathrm{C}$, and moisture level of $80 \%$ and obtained 175 to $3363 \mathrm{mg}$ with $1999 \%$ gain in biomass. The present study also reported 6 week period as the optimum incubation period for $\mathrm{Ee}$. Kadam $\&$ Pathade (2004) reported weight loss on $7^{\text {th }}$ and $8^{\text {th }}$ week of incubation for Eudrilus eugeniae which is similar to the present results.

Optimization of $\mathbf{p H}$ of feed for $\boldsymbol{E} \boldsymbol{e}$ : It was evident from Table 3 and Fig. 5 that pH 6.0 and below and at pH 8.0 and above of feed, average maximum weight gain for earthworm was less as compared to weight gain at $\mathrm{pH} 7.0$ and hence $\mathrm{pH} 7.0$ was taken as optimum for vermicomposting of BDS and PDFVW, and the experiment incubation period of six weeks was taken. The average maximum weight gain was found at $\mathrm{pH} 7$ for $E e$ earthworm species. The average maximum weight gain for the three sets of $E e$ on $6^{\text {th }}$ week was $2427.7 \pm 23.1$. The average growth rate has the maximum value at $\mathrm{pH} 7.0$ as $5.57 \pm 0.1$ for $E e$. The average growth rate $(\mathrm{mg} /$ worm/day) for $E e$ was reported as $3.31 \pm 0.11$. The vermicompost obtained at $\mathrm{pH} 7.0$ was $364.7 \pm 23.1 / \mathrm{g} / \mathrm{kg}$ of feed. Hence $\mathrm{pH} 7.0$ was considered as optimum.

The results of the present study are similar to previous studies by Gajlakshmi \& Abbasi (2004) who reported $\mathrm{pH}$ 7.0 as optimum and migration of earthworms if $\mathrm{pH}$ value

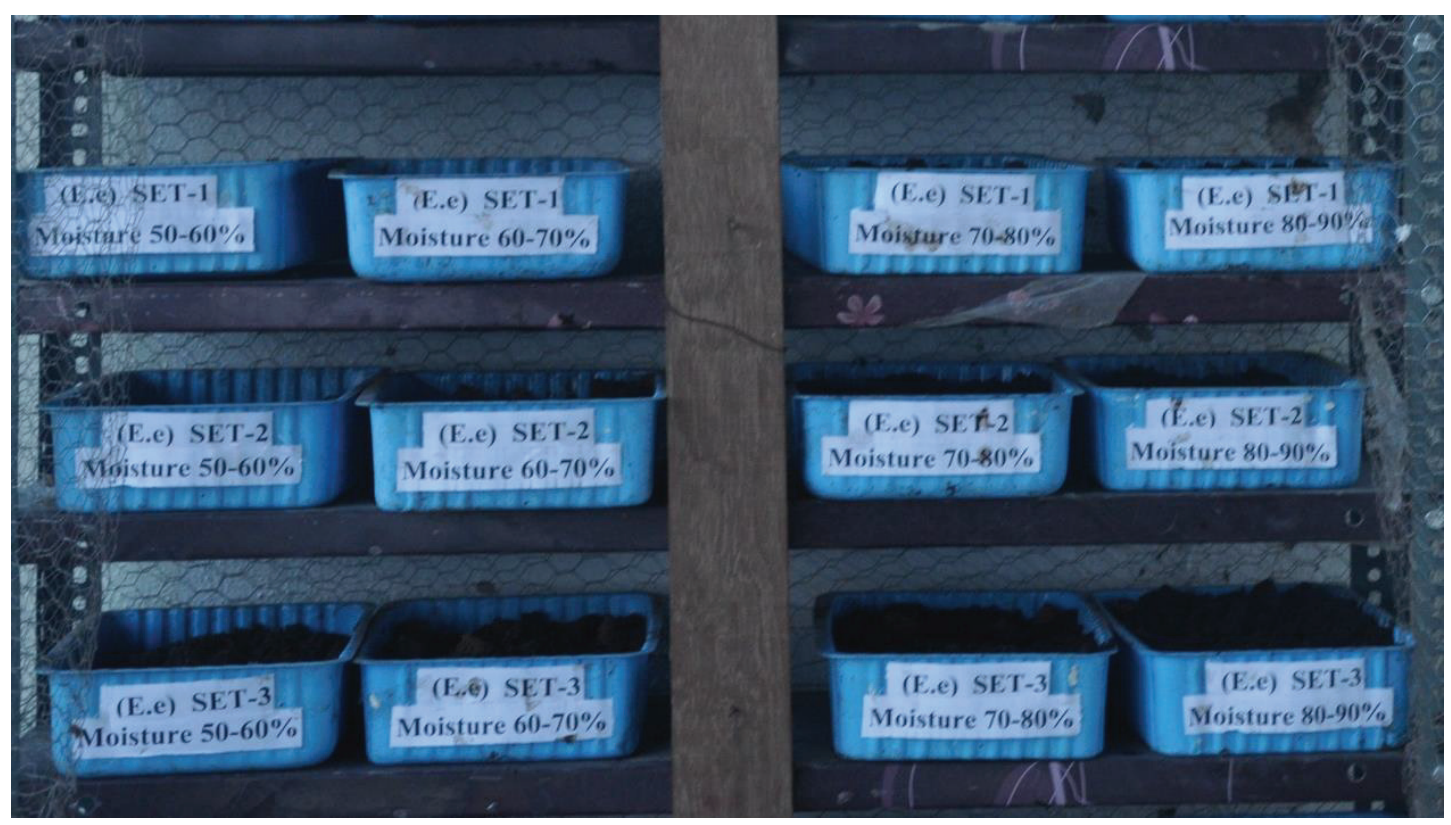

Fig. 3: Optimization of the moisture of feed for vermicomposting (trays in the rack) (Optimized conditions: incubation period 6 week, $\mathrm{pH}$ of feed 7.0 and moisture content of feed $70-80 \%$ ). 
Table 2: Optimization of the incubation period for $E e$ (mg/tray).

\begin{tabular}{|ll|}
\hline \multicolumn{2}{|c|}{ Incubation period : Average weight gain of Ee in (mg/tray) } \\
\hline Week of incubation & Average weight gain \\
\hline 0 & $83.35 \pm 3.6$ \\
1 & $166.83 \pm 20.42$ \\
2 & $318.01 \pm 47.23$ \\
4 & $601.56 \pm 68.14$ \\
5 & $995.85 \pm 49.14$ \\
6 & $1289.05 \pm 89.15$ \\
7 & $1936.64 \pm 64.05$ \\
8 & $1823 \pm 26.10$ \\
Average Total weight gain/tray/ & $1725.68 \pm 61.05$ \\
week & $999.6 \pm 39.7$ \\
Average growth rate (mg/tray/ & $44.1 \pm 1.4$ \\
day) & \\
Average growth rate (mg/worm/ & $4.4 \pm 0.14$ \\
day) & $348.9 \pm 21.5$ \\
Vermicompost (g/kg of feed) & \\
\hline
\end{tabular}

decreased below six. Kadam \& Pathade (2004) reported that the average maximum weight gain for $E e$ at $\mathrm{pH} 7$ was from $81.3 \mathrm{mg}$ to $3351 \mathrm{mg}$. Gurav \& Pathade (2012) reported that average maximum weight gain for $E e$ at $\mathrm{pH} 7$ was from 159mg to 7090mg, while Utekar \& Deshmukh (2016) reported average maximum weight gain for $E e$ at $\mathrm{pH} 7$ from $2400 \mathrm{mg}$ to $28660 \mathrm{mg}$.
Optimization of moisture content of the feed for $E \boldsymbol{e}$ : It is evident from Table 4 and Fig. 6 that there was a gradual increase in weight up to $70-80 \%$ moisture which then decreased. The results indicated that the maximum weight gain was at the moisture content $70-80 \%$. The average maximum weight gain for three sets of $E e$ on 6th week at 70-80\% moisture was 3263.8 \pm 201.6 (Table 4 and Fig. 6). The average maximum growth rate for $E e$ at the moisture content of $70-80 \%$ was found as $7.5 \pm 0.47 \mathrm{mg} /$ worm/day. The average total vermicompost obtained at the moisture level of 70-80\% and was $416.2 \pm 14.3 \mathrm{~g} / \mathrm{kg}$ of feed for $E e$.

The results of the present study seem to be almost similar to the previous reports. Kadam \& Pathade (2004) reported average maximum weight gain for $E e$ at the moisture of $70-80 \%$ was from $194 \mathrm{mg}$ to $3099 \mathrm{mg}$. Palsania et al. (2005) had reported faster vermicomposting rates for $E e$ at moisture \% of $75 \pm 5$. Gurav \& Pathade (2012) reported the average maximum weight gain for $E e$ at the moisture of $80 \%$ was from $171 \mathrm{mg}$ to $3585 \mathrm{mg}$. Pandit \& Maheshwari (2012) reported the average maximum weight gain for $E e$ at the moisture level of $80 \%$ was from $175 \mathrm{mg}$ to $3363 \mathrm{mg}$. Utekar \& Deshmukh (2016) reported average maximum weight gain for $\mathrm{Ee}$ at the moisture of $80 \%$ was from 2400 $\mathrm{mg}$ to $19720 \mathrm{mg}$.

The average maximum weight gain for earthworm $E e$ was found at 70-80\% moisture optimized conditions of six weeks incubation period, $\mathrm{pH} 7.0$ and feed ambient temperature of $25-30^{\circ} \mathrm{C}$.

At 50-60\% and 60-70\% moisture level the average weight

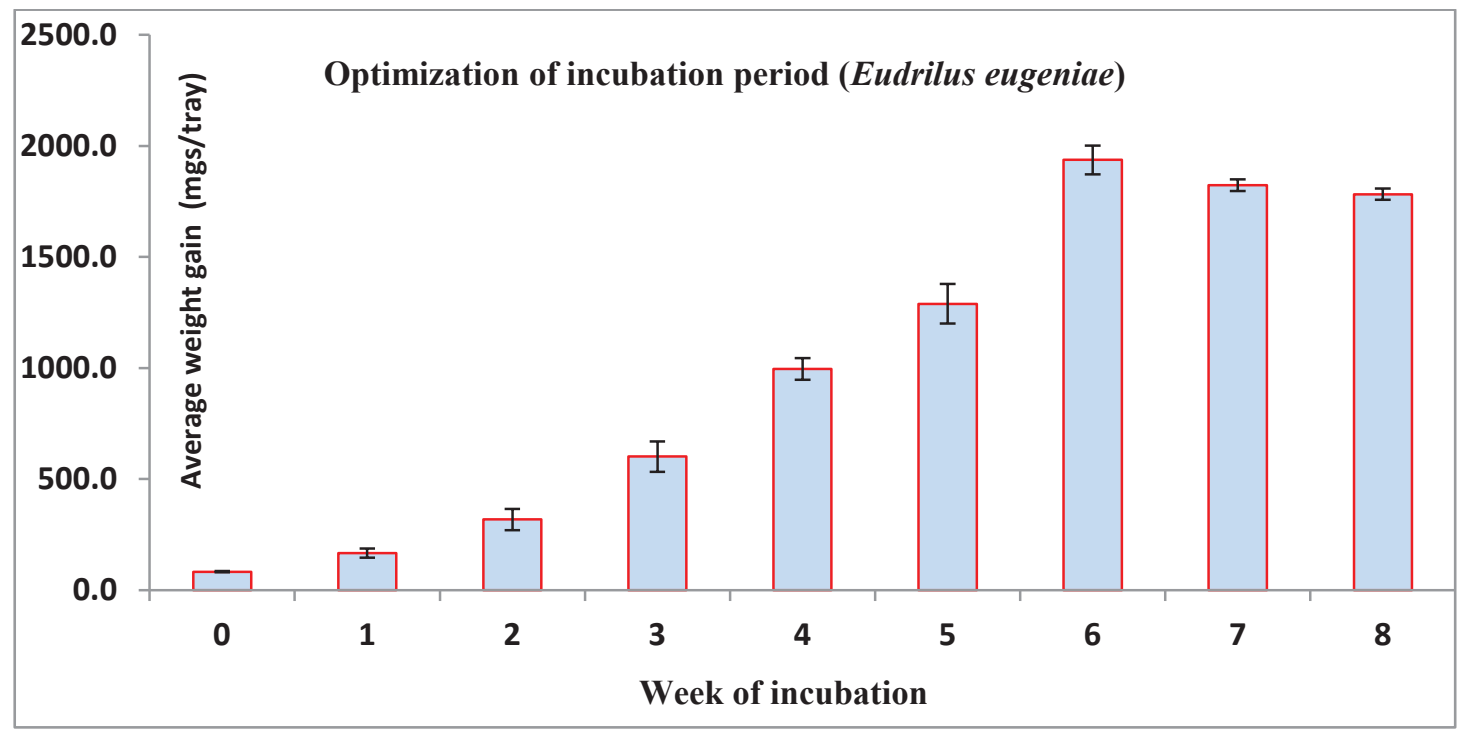

Fig. 4: Optimization of the incubation period for $E e$ and average weight gain (mg/tray). 
gain and average growth rate for the earthworms were less as compared to $70-80 \%$ for $E e$ hence $70-80 \%$ moisture content was taken as optimum for $E e$.

The optimized conditions for vermicomposting at $1 \mathbf{~ k g}$ tray level studies: The experiments conducted for optimization of $\mathrm{pH}$ and $\%$ moisture of substrate/feed and optimized sets of conditions for vermicomposting of BDS and PDFVW were as below: (Table 5).

Vermicomposting using the optimized set of conditions at $1 \mathrm{~kg}$ tray level study: The experiment was performed in triplicate at $1 \mathrm{~kg}$ tray level using optimized incubation period of 6th week, feed $\mathrm{pH} 7.0$ and $\%$ moisture of feed to $70-80 \%$ for $E e$. The average maximum weight gain of $E e$ found on the $6^{\text {th }}$ week was $3378.7 \pm 24.7 \mathrm{mg}$ and vermicompost produced was $485.7 \pm 6.7 \mathrm{~g} / \mathrm{kg}$ of feed. The $E e$ had a growth rate of $78.3 \pm 0.6 \mathrm{mg} /$ tray/day (Table 6 and Fig. 7).

It was further found that the average weight gain and growth rates increased when all the optimized conditions were used as compared to results at the time of optimization of individual conditions.

\section{CONCLUSIONS}

- The BDS and PDFVW are amenable to vermicomposting using $E e$.

- The earthworm Ee significantly produced the vermicompost from the above-mentioned substrate (feed).

Table 3: Optimization of $\mathrm{pH}$ of feed for $E e$ (mg/tray).

\begin{tabular}{|c|c|c|c|c|c|}
\hline \multicolumn{6}{|c|}{ Optimization of $\mathrm{pH}$ of $E e$ (mg/tray) } \\
\hline Week/pH of feed of incubation & $\mathrm{pH} 5$ & $\mathrm{pH} 6$ & $\mathrm{pH} 7$ & $\mathrm{pH} 8$ & $\mathrm{pH} 9$ \\
\hline 0 & $86.06 \pm 7.9$ & $94.9 \pm 8.1$ & $87.6 \pm 6.3$ & $92.4 \pm 4.1$ & $83 \pm 11.0$ \\
\hline 1 & $184.73 \pm 10.71$ & $185.77 \pm 21.39$ & $207.57 \pm 6.37$ & $177.47 \pm 33.25$ & $173.1 \pm 24.04$ \\
\hline 2 & $184.33 \pm 22.96$ & $239.73 \pm 26.48$ & $362.03 \pm 15.49$ & $241.73 \pm 46.15$ & $168.8 \pm 18.19$ \\
\hline 3 & $189.53 \pm 3.84$ & $315.3 \pm 23.51$ & $706.3 \pm 16.67$ & $340.33 \pm 44.06$ & $184.1 \pm 20.74$ \\
\hline 4 & $208.67 \pm 11.8$ & $397 \pm 13.66$ & $1034.67 \pm 64.72$ & $415.5 \pm 39.65$ & $206.83 \pm 29.82$ \\
\hline 5 & $234.0 \pm 6.13$ & $493 \pm 35.55$ & $1512 \pm 23.82$ & $505.57 \pm 23.53$ & $234.57 \pm 40.11$ \\
\hline 6 & $228.1 \pm 16.74$ & $619.37 \pm 21.04$ & $2427.67 \pm 23.08$ & $611.8 \pm 12.5$ & $274 \pm 48.37$ \\
\hline Average Total weight gain/tray/week & $187.9 \pm 8.2$ & $423.9 \pm 6.3$ & $905.4 \pm 8.9$ & $340.7 \pm 26.3$ & $189.2 \pm 27.6$ \\
\hline Average growth rate (mg/tray/day) & $3.5 \pm 0.02$ & $17.3 \pm 0.02$ & $55.7 \pm 0.6$ & $12.4 \pm 0.04$ & $4.5 \pm 0.9$ \\
\hline Average growth rate (mg/worm/day) & $0.35 \pm 0.02$ & $1.73 \pm 0.02$ & $5.57 \pm 0.1$ & $1.24 \pm 0.04$ & $0.45 \pm 0.1$ \\
\hline Vermicompost ( $\mathrm{g} / \mathrm{kg}$ of feed) & $163.1 \pm 12.7$ & $247.3 \pm 14.8$ & $364.7 \pm 23.1$ & $263.4 \pm 11.2$ & $187.4 \pm 13.6$ \\
\hline
\end{tabular}

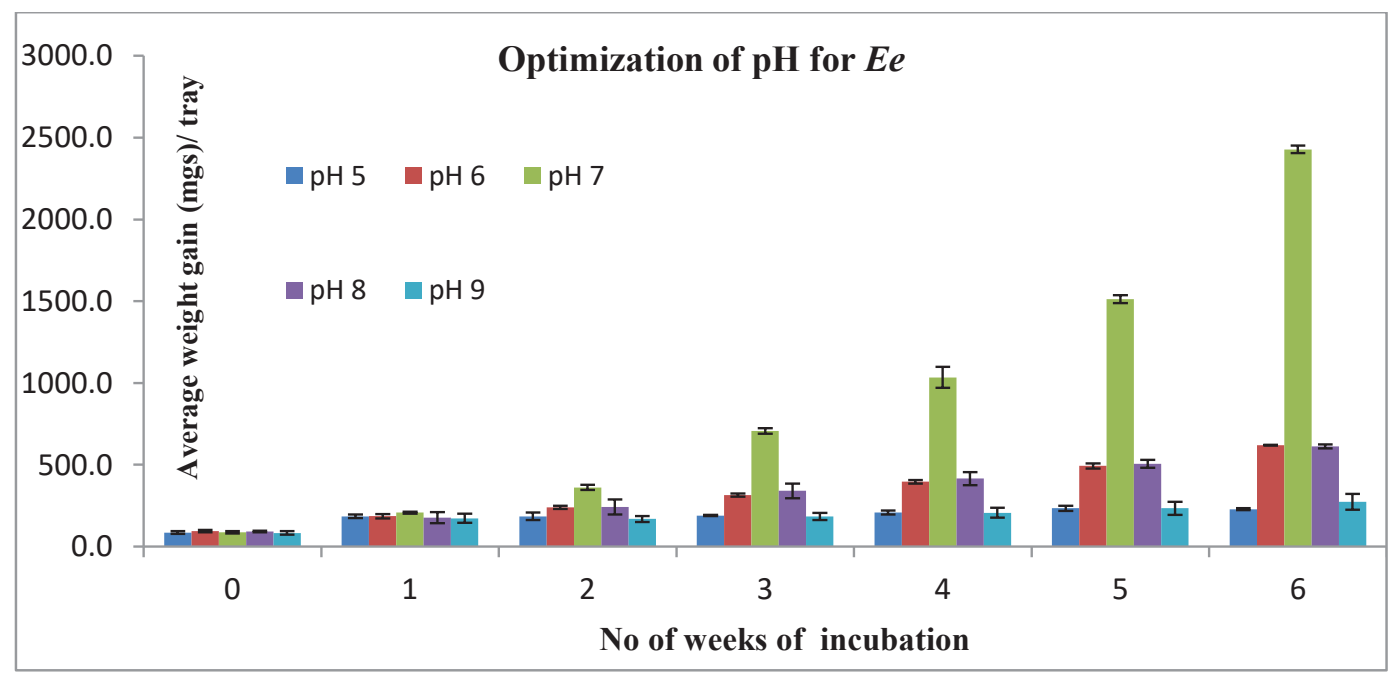

Fig. 5: Optimization of $\mathrm{pH}$ of feed for $E e$ (mg/tray). 
- The optimized $\mathrm{pH}$ of feed for vermicomposting of BDS and PDFVW was pH 7.0.

- The optimized moisture range of feed was $70-80 \%$ for $E e$.

- The average growth rate for $E e$ using at $1 \mathrm{~kg}$ feed with optimized conditions was found to be $7.8 \pm 0.06 \mathrm{mg} /$ worm/day.

- The vermicompost obtained using all the optimized conditions was $485.7 \pm 6.7 \mathrm{~g} / \mathrm{kg}$ of feed

\section{REFERENCES}

Ansari, A.A. and Ismail, S.A. 2012. Earthworms and vermiculture biotechnology. In: Sunil Kumar and Ajay Bharti (Eds.) Management of Organic Waste, pp. 87-96.

Bansal, S. and Kapoor, K.K. 2000. Vermicomposting of crop residues and cattle dung with Eisenia fetida. Biores. Technol., 73(2): 95-98.

Butt, K.R. and Lowe, C.N. 2011. Controlled cultivation of endogeic and anecic earthworms. In: Biology of Earthworms. Springer, Berlin, Heidelberg, pp. 107-121

Table 4: Optimization of moisture content of feed for $E e$ (mg/tray).

\begin{tabular}{|lllll|}
\hline \multicolumn{4}{c|}{ Optimization of moisture content for $E e$ (mg/tray) } \\
\hline Week/Moisture (\%) of feed of incubation & $50-60$ & $60-70$ & $70-80$ & $80-90$ \\
\hline 0 & $82.7 \pm 7.71$ & $86.57 \pm 7.39$ & $92.23 \pm 5.73$ & $84.97 \pm 7.02$ \\
1 & $161.3 \pm 12.1$ & $192.9 \pm 29.2$ & $200.4 \pm 15$ & $167.5 \pm 20.3$ \\
2 & $219.6 \pm 25.9$ & $297.5 \pm 46.7$ & $338.5 \pm 19.9$ & $334.2 \pm 42.3$ \\
3 & $283.8 \pm 22.6$ & $406 \pm 57.9$ & $805.2 \pm 20.6$ & $661.6 \pm 93.5$ \\
4 & $359.8 \pm 28.9$ & $529.5 \pm 51.2$ & $1340.1 \pm 77.7$ & $1026.9 \pm 107.2$ \\
5 & $440.7 \pm 32.3$ & $806.7 \pm 103.2$ & $1756.6 \pm 209$ & $1537.9 \pm 75.7$ \\
6 & $594.47 \pm 54$ & $1231.8 \pm 180$ & $3263.7 \pm 201.6$ & $2241.9 \pm 111.4$ \\
Average Total weight gain/ tray/week & $306.08 \pm 25.74$ & $507.3 \pm 39.12$ & $1113.8 .0 \pm 65.59$ & $865.01 \pm 56.14$ \\
Average growth rate (mg/tray/day) & $12.18 \pm 1.1$ & $27.27 \pm 4.1$ & $75.5 \pm 0.4 .6$ & $51.36 \pm 2.5$ \\
Average growth rate (mg/worm/day) & $1.22 \pm 0.12$ & $2.73 \pm 0.41$ & $7.5 \pm 0.47$ & $5.14 \pm 0.25$ \\
Vermicompost (g/kg of feed) & $362.3 \pm 16.7$ & $374.8 \pm 17.4$ & $416.2 \pm 14.3$ & $386.2 \pm 12.7$ \\
\hline
\end{tabular}

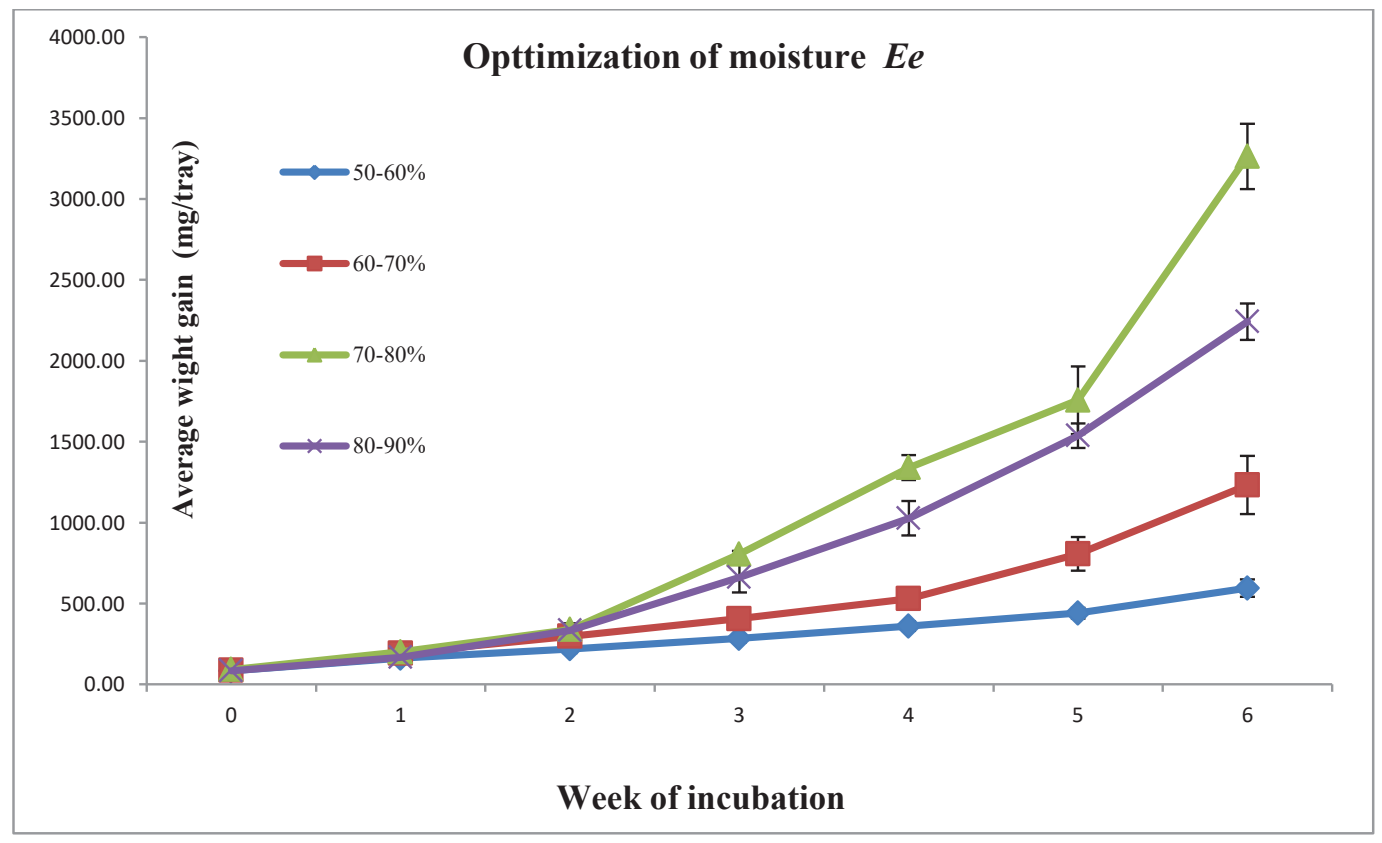

Fig. 6: Optimization of moisture content (average weight gain) for $E e$ (mg/tray). 


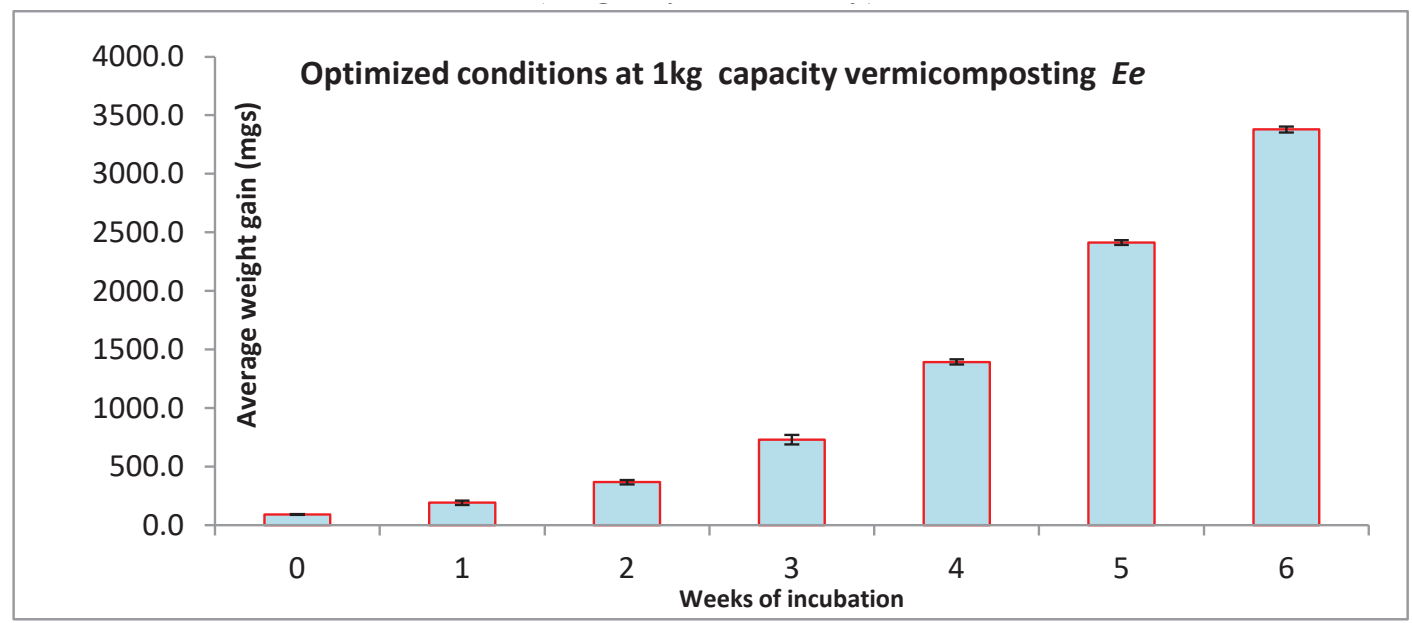

Fig. 7: Vermicomposting using the optimized set of conditions using $E e$ (1 kg tray level study).

Table 5: Optimized conditions for vermicomposting.

\begin{tabular}{|ll|}
\hline Parameter & $E e$ \\
\hline $\mathrm{pH}$ & 7 \\
Moisture $(\%)$ & $70-80$ \\
Temperature (ambient $\left.{ }^{0} \mathrm{C}\right)$ & $25-30$ \\
Incubation period (weeks) & 6 \\
\hline
\end{tabular}

Table 6: Vermicomposting results for optimized conditions for vermicomposting.

\begin{tabular}{|ll|}
\hline \multicolumn{2}{|c|}{ Vermicomposting using the optimized set of conditions with $E e$} \\
\hline Weeks of incubation & Average weight gain (mg/tray) \\
\hline 0 & $90.9 \pm 3.2$ \\
1 & $190.7 \pm 19$ \\
2 & $366.23 \pm 18.6$ \\
3 & $729.7 \pm 39.4$ \\
4 & $1392.5 \pm 22.1$ \\
5 & $2413.56 \pm 19.7$ \\
6 & $3378.7 \pm 24.7$ \\
Average Total weight gain/ tray/ & $1223.2 \pm 1.4$ \\
week & \\
$\begin{array}{l}\text { Average growth rate (mg/tray/ } \\
\text { day) }\end{array}$ & $78.3 \pm 6.1$ \\
$\begin{array}{l}\text { Average growth rate (mg/worm/ } \\
\text { day) }\end{array}$ & $7.8 \pm 0.6$ \\
Vermicompost (g/kg of feed) & $485.7 \pm 6.7$ \\
\hline
\end{tabular}

Devi, G.S., Karthiga, A., Susila, S. and Muthunarayanan, V. 2012. Bioconversion of fruit waste into vermicompost by employing Eudrillus eugeniae and Eisenia foetida. International Journal of Plant, Animal and Environmental Sciences, 2(4): 245-252.
Gajalakshmi, S. and Abbasi, S.A. 2004. Earthworms and vermicomposting. Indian Journal of Biotechnology, 3: 486-494.

Gurav, M.V. and Pathade, G.R. 2011. Production of vermicompost from temple waste (Nirmalya): A case study. Universal Journal of Environmental Research and Technology, 1(2): 182-192.

Hemalatha, B. 2013. Comparative evaluation of biodegradability of yard waste and fruit waste with industrial effluents by vermicomposting. Int. J. Adv. Eng. Technol., 2(2): 36-39.

Kadam, D.G. and Pathade, G.R. 2004. Studies on vermicomposting of tendu leaf Diospyros melanoxylon Roxb. refuse with emphasis on microbiological and biochemical aspects. Ph.D. Thesis.

Kale, R.D., Bano, K. and Krishnamoorthy, R.V. 1982. Potential of Perionyx excavatus for utilizing organic wastes. Pedobiologia, 23(6): 419-425.

Manaf, L.A., Jusoh, M.L.C., Yusoff, M.K., Ismail, T.H.T., Harun, R., Juahir, H. and Jusoff, K. 2009. Influences of bedding material in vermicomposting process. International Journal of Biology, 1(1): 81.

Mane, T.T. and Raskar Smita, S. 2012. Management of agriculture waste from market yard through vermicomposting. Research Journal of Recent Sciences, 1(ISC-2011): 289-296.

Manyuchi, M.M. and Phiri, A. 2013. Vermicomposting in solid waste management: A review. International Journal of Scientific Engineering and Technology, 2(12): 1234-1242.

Mathew, J. 2006. The impact of new economic policy on Indian agriculture a study of selected cash crops. Thesis. Department of Economics, Dr. John Matthai Centre, University of Calicut.

Palsania, J., Sharma, R., Srivastava, J.K. and Sharma, D. 2008. Effect of moisture content variation over kinetic reaction rate during vermicomposting process. J. Applied Ecology and Environmental Research, 6(2): 49-61.

Pandit, N.P. and Maheshwari, S.K. 2012. Optimization of vermicomposting technique for sugarcane waste management by using $E f$. Int. J. Biosci., 10(1): 143-155.

Suthar, S. 2009. Vermicomposting of vegetable-market solid waste using Eisenia fetida: Impact of bulking material on earthworm growth and decomposition rate. Ecological Engineering, 35(5): 914-920.

Utekar, G. and Deshmukh, H. 2016. Optimization of parameters for preparation of vermicompost from bagasse and press mud by using $E e$. Res J. Chem. Environ. Sci., 4(3): 67-70. 